\title{
DIAGNOSIS AND TREATMENT CHILDREN WITH ACUTE SCROTAL PAIN. TWENTY YEARS SINGLE CENTRE EXPERIENCE
}

Minaev S. V., Bolotov lu. N.

Stavropol State Medical University, Stavropol, Russian Federation

\section{АВААЦАТИАЕТНИЙ ОПЫТ АИАГНОСТИКИ И АЕЧЕНИЯ АЕТЕЙ С СИНАРОМОМ ॥ОСТРОЙ МОШОНКИ॥}

\author{
С. В. Минаев, Ю. Н. Болотов
}

\section{Ставропольский госуАарственный меАицинский университет, Ставрополь, Российская ФеАерация}

The aim of study was to determine the value of Doppler ultrasonography in the diagnosis of acute scrotal pain in the different stages of acute scrotum.

The case notes of 344 boys with an acute scrotum aged from 1 st day of life to 17 years old were reviewed in the Department of Pediatric Surgery of StSMU (Russia). The size and ultrasonography structure of the testis and its epididymis, as well as the testicular blood flow, were assessed.

The sensitivity of ultrasonography findings for testicular torsion without scrotal edema was relatively low (50\%), but with scrotal edema - increased to $83.3 \%$. The specificity of sonography for testicular torsion in the presence or absence of edema of the scrotum did not change significantly (83.2\%). The characteristic ultrasonography evidence of torsion of a testicular appendage was an increase in size of the epididymis and its heterogeneous echostructure. The sensitivity of these signs was high (83.3\%) in all boys. The sonography signs of acute epididymitis are an enlarged epididymis and its homogeneity. The sensitivity $(83.3 \%)$ and specificity $(87.5 \%)$ of the findings did not depend on the presence or absence of scrotal edema. Operative exploration was performed on 240 patients. Surgical findings were: testicular torsion 61 , torsion of a testicular appendage -164 , acute epididymitis -20 .

Thus, the sensitivity and specificity of physical examination signs of the acute scrotum in the absence of scrotal edema in children are higher than the ultrasonography findings, but significantly drops after the onset of scrotal edema.

Key words: scrotal pain, testicular torsion, diagnosis management, children

Цель исследования - определить диагностические возможности допплеровского ультразвукового исследования при острых заболеваниях яичка у детей в разные периоды заболевания.

Было обследовано 344 мальчика в возрасте от 1 дня жизни до 17 лет с синдромом «острой мошонки». При ультразвуковой допплерографии оценивали размер и эхоструктуру яичка и его придатка, а также показатели внутриорганного кровотока.

Чувствительность ультразвуковых симптомов перекрута яичка в отсутствие отека и гиперемии мошонки была достаточно низкой (50\%), однако значительно возрастала при присоединении воспалительных явлений со стороны мошонки (до 83,3\%). Специфичность ультразвуковых симптомов перекрута яичка от стадии заболевания не зависела и составляла 83,2\%. Характерными ультразвуковыми симптомами перекрута гидатиды были увеличение размеров придатка и гетерогенность его структуры. Чувствительность этих признаков была достаточно высокой (83,3\%). Ультразвуковыми симптомами острого эпидидимита являлись: незначительное увеличение придатка яичка при сохранении его гомогенности. Чувствительность и специфичность этих признаков были высокими (83,3 и 87,5\% соответственно) и не зависели от наличия или отсутствия отека и гиперермии мошонки. Всего было прооперировано 240 детей, из них: с перекрутом яичка - 61, с перекрутом гидатиды - 164 и с острым эпидидимитом - 20.

Таким образом, чувствительность и специфичность клинических симптомов при острых заболеваниях яичка при отсутствии отека и гиперемии мошонки превышает таковые показатели ультразвуковых симптомов. С появлением отека и гиперемии мошонки ультразвуковые симптомы становятся достоверно чувствительнее клинических данных.

Ключевые слова: острая боль, мошонка, перекрут яичка, диагностика, дети 
T he acute painful scrotum is one of the most challenging urological emergencies $[1,2,3]$. Making the correct diagnosis of testicular torsion, torsion of a testicular appendage, or acute epididymitis can be difficult because pathognomonic findings are infrequently present $[4,5]$. Delayed diagnosis and treatment can potentially lead to irreversible parenchymal damage and loss of a testis. The introduction of color Doppler sonography has reduced the number of diagnostic explorations. Doppler ultrasonography (US) for the diagnosis of testicular torsion had a $94 \%$ sensitivity, $96 \%$ specificity, $95.5 \%$ accuracy, an $89.4 \%$ positive predictive value, and a $98 \%$ negative predictive value in one study [6]. In another study, US yielded a sensitivity of $69.2 \%$, specificity of $100 \%$, positive predictive value of $100 \%$ and negative predictive value of $\mathbf{9 7 . 5 \%}$ for torsion [7]. In $84 \%$ of children with acute scrotal pain, the DUS was able to differentiate between a surgical emergency and other etiologies [8]. However, the color Doppler sonography of scrotum at times can show significant false-negative results $[9,10,11]$. If clinical suspicion of testicular torsion persists after US, the patient should still undergo scrotal exploration [12]. Also, some pediatric surgeons believe that any boy with acute scrotal pain and suspicion of testicular torsion on physical examination should undergo scrotal exploration [13]. Therefore a number of clinicians do not perform additional examination of children with "acute scrotum" and proceed directly to operative intervention [14].

Our hypothesis is that the accuracy of clinical examination and US for acute scrotal pain in childhood varies during different stages of the disease. The aim of this study was to determine the value of US in the diagnosis of acute scrotal pain in the different stages of the disease.

Material and Methods. The case notes of 344 boys with an acute scrotum aged from 1st day of life to 17 years old were reviewed in the Department of Pediatric Surgery of Stavropol State Medical University at the Regional Pediatric Hospital of Stavropol (Russia) from 1991 to 2010. The study included all males diagnosed or admitted with an acute scrotum. Physical findings reviewed were position, size and mobility of the testis, location of testicular tenderness, the presence of a palpable nodule at the superior aspect of the testicle (blue-dot sign), and scrotal edema. All patients had blood and urine tests.

Patients underwent testicular US with Color Doppler by GE Pro series LOGIQ 500 and SonoAce PICO $7.5 \mathrm{MHz}$ transducer. The size and echo structure of the testis and its epididymis, as well as the testicular blood flow, were assessed and documented.

Based on the results from the clinical findings and US examination, further management and treatment was planned. For both the physical examination signs and US findings, sensitivity (Se) and specificity (Sp) were determined.

Results. Torsion of a testicular appendage was diagnosed in 205 children (59.6\%), acute epididymitis in 78 (22.7\%), and testicular torsion in 61
$(17.7 \%)$. Based on these results, we have calculated the sensitivity and specificity for clinical and US signs of testicular torsion, torsion of a testicular appendage, and epididymitis.

The sensitivity of the physical examination signs for testicular torsion (elevation of the testis, transverse lie, and diffuse tenderness of the testis) in the absence of scrotal edema was very high (Se-98.5\%). However, in boys with scrotal edema, the sensitivity of these signs of testicular torsion was dramatically reduced (Se $-8.3 \%)$. The specificity of the signs remains high ( $\mathrm{Sp}-95.8 \%$ ), both in the presence and absence of scrotal edema.

Physical examination signs of torsion of a testicular appendage (a blue-dot sign or palpable tender nodule at the superior aspect of the testis) showed high sensitivity in patients without scrotal edema (Se - 97.3\%). If scrotal edema is present, the sensitivity of the listed signs declined considerably (Se $-25.5 \%$ ). However, the specificity of physical examination signs for torsion of a testicular appendage in boys without scrotal edema was high (Sp - 68.5\%), and increased with the development of edema in $96 \%$. Characteristic local symptoms of acute epididymitis were identified (Table 1).

Table 1

General data of the physical examination of acute scrotum in children

\begin{tabular}{|c|c|c|c|c|c|c|}
\hline \multirow{3}{*}{ Index } & \multicolumn{2}{|c|}{$\begin{array}{c}\text { Testicular } \\
\text { torsion } \\
n=61\end{array}$} & \multicolumn{2}{|c|}{$\begin{array}{c}\text { Torsion } \\
\text { of testicular } \\
\text { appendage } \\
n=205\end{array}$} & \multicolumn{2}{|c|}{$\begin{array}{c}\text { Acute } \\
\text { epididymitis } \\
n=78\end{array}$} \\
\hline & \multicolumn{2}{|c|}{ scrotal edema } & \multicolumn{2}{|c|}{ scrotal edema } & \multicolumn{2}{|c|}{ scrotal edema } \\
\hline & $\begin{array}{c}\text { yes } \\
(n=55)\end{array}$ & $\begin{array}{c}\text { no } \\
(n=6)\end{array}$ & $\begin{array}{c}\text { yes } \\
(n=164)\end{array}$ & $\begin{array}{c}\text { no } \\
(n=41) \\
\end{array}$ & $\begin{array}{c}\text { yes } \\
(n=54)\end{array}$ & $\begin{array}{c}\text { no } \\
(n=24) \\
\end{array}$ \\
\hline $\begin{array}{l}\text { Elevation } \\
\text { of the } \\
\text { testis }\end{array}$ & $\begin{array}{c}7 \\
(12.7 \%)\end{array}$ & $\begin{array}{c}6 \\
(100 \%)\end{array}$ & $\begin{array}{c}20 \\
(12.2 \%)\end{array}$ & $\begin{array}{c}7 \\
(17.1 \%)\end{array}$ & $\begin{array}{c}6 \\
(11.1 \%)\end{array}$ & - \\
\hline $\begin{array}{l}\text { Transverse } \\
\text { lie of the } \\
\text { testis }\end{array}$ & $\begin{array}{c}3 \\
(5.5 \%)\end{array}$ & $\begin{array}{c}6 \\
(100 \%)\end{array}$ & - & - & - & - \\
\hline \begin{tabular}{|l|} 
Diffuse \\
tenderness \\
Tenderness \\
is localized \\
to the up- \\
per pole of \\
the testis \\
\end{tabular} & $\begin{array}{c}53 \\
(96.4 \%)\end{array}$ & $\begin{array}{c}6 \\
(100 \%)\end{array}$ & $\begin{array}{c}103 \\
(62.8 \%)\end{array}$ & $\begin{array}{c}41 \\
(100 \%)\end{array}$ & $\begin{array}{c}51 \\
(94.5 \%)\end{array}$ & $\begin{array}{c}12 \\
(50 \%)\end{array}$ \\
\hline \begin{tabular}{|l|} 
Parates- \\
ticular \\
nodule at \\
the supe- \\
rior aspect \\
of the \\
testicle \\
\end{tabular} & $\begin{array}{c}2 \\
(3.3 \%)\end{array}$ & - & $\begin{array}{c}21 \\
(12.8 \%)\end{array}$ & $\begin{array}{c}41 \\
(100 \%)\end{array}$ & $\begin{array}{c}3 \\
(5.5 \%)\end{array}$ & $\begin{array}{c}9 \\
(37.5 \%)\end{array}$ \\
\hline
\end{tabular}

With regards to US, the sensitivity of US findings for testicular torsion (increase in size of testis and its epididymis in conjunction with the heterogeneity of its echostructure) in boys without scrotal edema was relatively low (50\%). When scrotal edema was present, the sensitivity of US increased to $83.3 \%$. The specificity of US for testicular torsion in the presence or absence of edema of the scrotum did not change significantly, and was $83.2 \%$ on average. 
The characteristic US evidence of torsion of a testicular appendage was an increase in size of the epididymis and its heterogeneous echostructure. The sensitivity of these signs was high (83.3\%), and was not different in boys with or without scrotal edema. These US findings showed high specificity in infants without scrotal edema $(77.5 \%)$ and increased to $90 \%$ with scrotal edema.
The US signs of acute epididymitis are an enlarged epididymis and its homogeneity. The sensitivity and specificity of the findings (Table 2) did not depend on the presence or absence of scrotal ede$\mathrm{ma}(\mathrm{Se}-83.3 \%, \mathrm{Sp}-87.5 \%)$.

General data of the ultrasound examination of acute scrotum in children

\begin{tabular}{|c|c|c|c|c|c|c|}
\hline \multirow{3}{*}{ Index } & \multicolumn{2}{|c|}{$\begin{array}{c}\text { Testicular torsion } \\
n=61\end{array}$} & \multicolumn{2}{|c|}{$\begin{array}{l}\text { Torsion of testicular appendage } \\
n=205\end{array}$} & \multicolumn{2}{|c|}{$\begin{array}{l}\text { Acute epididymitis } \\
\mathrm{n}=78\end{array}$} \\
\hline & scrot & ema & scrot & lema & scrota & ema \\
\hline & yes $(n=55)$ & no $(n=6)$ & yes $(n=164)$ & no $(n=41)$ & yes $(n=54)$ & no $(n=24)$ \\
\hline $\begin{array}{l}\text { Testicular size } \\
\text { - large }\end{array}$ & $47(85.5 \%)$ & - & - & - & - & - \\
\hline - normal & $8(14.5 \%)$ & $6(100 \%)$ & $164(100 \%)$ & $41(100 \%)$ & $54(100 \%)$ & $24(100 \%)$ \\
\hline $\begin{array}{l}\text { Epididymis size } \\
\text { - large } \\
\text { - normal } \\
\end{array}$ & $\begin{array}{c}47(85.5 \%) \\
8(14.5 \%)\end{array}$ & $6(100 \%)$ & $\begin{array}{c}164(100 \%) \\
-\end{array}$ & $\begin{array}{c}34(82.9 \%) \\
7(17.1 \%)\end{array}$ & $\begin{array}{l}12(22.2 \%) \\
41(77.8 \%) \\
\end{array}$ & $24(100 \%)$ \\
\hline $\begin{array}{l}\text { Testicular } \\
\text { structure } \\
\text { - heterogenous } \\
\text { - homogenous }\end{array}$ & $55(100 \%)$ & $\begin{array}{c}6(100 \%) \\
-\end{array}$ & $164(\overline{100 \%)}$ & $41(100 \%)$ & $54(\overline{100 \%)}$ & $24(100 \%)$ \\
\hline \begin{tabular}{|l|} 
Epididymis \\
structure \\
- heterogenous \\
- homogenous
\end{tabular} & $55(100 \%)$ & $\begin{array}{c}6(100 \%) \\
-\end{array}$ & $\begin{array}{c}164(140 \%) \\
-\end{array}$ & $\begin{array}{c}41(100 \%) \\
-\end{array}$ & $54(\overline{100 \%)}$ & $24(100 \%)$ \\
\hline
\end{tabular}

Blood tests in children with an acute scrotum sho wed leukocytosis, lymphocytosis neutrophilia, eosinophilia and an accelerated sedimentation rate. Leukocytosis was observed more frequently with testicular torsion (29.5\%) and less often in epididymitis (23.1\%) and torsion of testicular appendage $(9.8 \%),(p<0.05)$. Lymphocytosis was typical for epididymitis (50\%), but not for testicular torsion (33.2\%) or testicular appendage torsion $(14.8 \%),(p<0.05)$. Other indicators of blood tests showed no significant differences $(p>0.05)$.

Urine tests in children with an acute scrotum showed proteinuria, hematuria and pyuria. Proteinuria was observed more often in boys with torsion of the testis (16.6\%) than with epididymitis or torsion of testicular appendage $(3.9 \%$ and $2.9 \%$, respectively) $(p<0.05)$. Pyuria was characteristic of epididymitis $(20.5 \%)$. In boys with testicular torsion, pyuria was rare $(8.2 \%)$, and was not found for testicular torsion appendage $(p<0.05)$. Hematuria occurred equally often with testicular torsion (24.4\%), torsion of the testicular appendage (22.9\%), and epididymitis (12.8\%), ( $p>0.05)$.

Operative exploration was performed on 240 patients with an acute scrotum. Surgical findings were: testicular torsion 61 , torsion of testicular appendage -164 , acute epididymitis - 20. In the 61 boys with testicular torsion, the testis was removed in 16, but was salvaged in 45 .

Discussion. From our data, the sensitivity of physical examination for testicular torsion and torsion of a testicular appendage in boys without scrotal edema was very high, but dropped significantly when scrotal edema was present. The sensitivity of US findings for an acute scrotum was low in the early stages of disease and increased with the development of scrotal edema.

Scrotal edema significantly impedes palpation of the testis and epididymis. At the same time, edema of scrotum is not an obstacle for US beams. Based on this study, a diagnostic and treatment algorithm has been developed for boys with an acute scrotum (Figure).

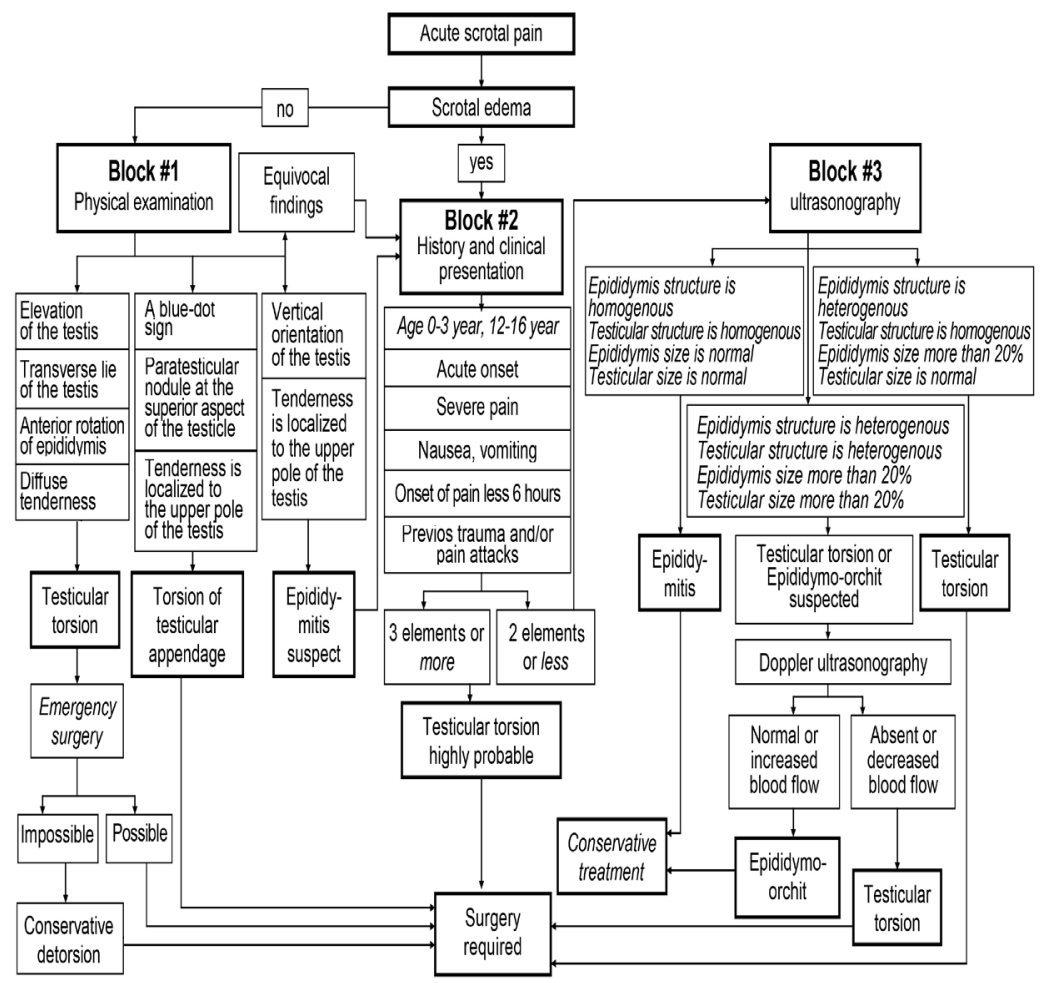

Fig. Algorithm for the diagnosis and 3 management of the acute scrotum in children 
The proposed algorithm relies on three principles:

1. Testicular torsion should be highly considered in males with acute scrotal pain until confidently excluded.

2. Scrotal US should be used in cases where spermatic cord torsion is suspected clinically.

3. In the absence of scrotal edema, the diagnostic value of clinical findings is higher than with US. The

\section{References}

1. Drlík M., Kočvara R. Torsion of spermatic cord in children: a review. J Pediatr Urol. 2013 Jun;9(3):259-266. doi: 10.1016/j.jpurol.2012.05.016. Epub 2012. Jul 2

2. Minaev S. V, Bolotov lu. N., Pavliuk N. N. The use of ultrasonography in the acute scrotum edema in children. Khirurgiia (Mosk) 2008; (4): 55-58.

3. Minaev S. V., Bolotov lu. N., Albert A. E., Prislegina D. A., Butko M. V. The torsion of testis in 1 year old infant. Meditsinskii Vestnik Severnogo Kavkaza. - Medical News of North Caucasus. 2011; 3(23): 112-114.

4. Jaison A., Mitra B., Cameron P. and Sengupta S. Use of ultrasound and surgery in adults with acute scrotal pain. ANZ Journal of Surgery. 2011; 81: 366-370. doi: 10.1111/j.1445-2197.2010.05535x

5. Tiemstra J. D., Kapoor S. Evaluation of scrotal masses. Am Fam Physician. 2008; 78(10): 1165-1170.

6. Yagil Y., Naroditsky I., Milhem J. et al. Role of Doppler ultrasonography in the triage of acute scrotum in the emergency department. J Ultrasound Med. 2010; 29: 11-21.

7. Kalisvaart J. F., Broecker B., Cerwinka W. H., Cuda S. Elmore J., Kaye J. et al. Pediatric chronic orchalgia. $J$ Pediatr Urol. 2012 Aug;8(4):421-425. doi: 10.1016/j. jpurol.2011.09.002. Epub 2011 Nov 4 diagnostic value of US significantly exceeds the clinical examination when scrotal edema has developed.

Conclusions. In summary, the Doppler US is a highly sensitive preoperative diagnostic tool for scrotal pain. The sensitivity and specificity of physical examination signs of the acute scrotum in the absence of scrotal edema in children are higher than the US findings, but significantly drops after the onset of scrotal edema.

8. Schalamon J., Ainoedhofer H., Schleef .J et al. Management of acute scrotum in children the impact of Doppler ultrasound. J Pediatr Surg. 2006; 41: 1377-1380.

9. Kalfa N., Veyrac C., Lopez M. et al. Multicenter assessment of ultrasound of the spermatic cord in children with acute scrotum. J Urol. 2007; 177(1): 297-301

10. Frauscher F., Klauser A., Radmayr C. Ultrasonographic assessment of the scrotum. Lancet. 2001; 3; 357(9257): $721-722$

11. Varga J., Zivkovic D., Grebeldinger S. et al. Acute scrotal pain in children-ten years' experience. Urol Int. 2007; 78(1): 73-77.

12. Sorensen M. D., Galansky S. H., Striegl A. M. et al. Perinatal extravaginal torsion of the testis in the first month of life is a salvageable event. Urology. 2003; 62(1): 132134.

13. Murphy F. L., Fletcher L., Pease P. Early scrotal exploration in all cases is the investigation and intervention of choice in the acute paediatric scrotum. Pediatr Surg Int. 2006; 22(5): 413-416. Epub 2006 Apr 7

14. Kraft K. H., Lambert S. M., Snyder H. M. 3rd, Canning D. A. Pyocele of the scrotum in the pediatric patient. J Pediatr Urol. 2012; Oct;8(5): 504-508. doi: 10.1016/j. jpurol.2011.10.005. Epub 2011 Nov 22

\title{
About authors:
}

Minaev Sergey Victorovich, Professor, MD, PhD (corresponding author) Head of Department of Pediatric Surgery, Stavropol State Medical University, Russia; tel.: +79624507653; e-mail: sminaev@yandex.ru

Bolotov Iuriy Nikolaevich, Assistant of Professor, MD; Department of Pediatric Surgery, Stavropol State Medical University, Russia; tel.: +79187838354; e-mail: b-y-n@rambler.ru

(C) Group of authors, 2015

UDC 616.125.127.8-009.3

DOI - http://dx.doi.org/10.14300/mnnc.2015.10027

ISSN - 2073-8137

\section{PREVENTION OF NEW-ONSET ATRIAL FIBRILLATION AFTER DIRECT MYOCARDIAL REVASCULARIZATION SURGERY: RANDOMIZED COMPARATIVE STUDY}

Kolesnikov V. N. ${ }^{2}$, Boeva O. I. ${ }^{1}$, Yagoda A. V. ${ }^{1}$, Ivanenko A. S. ${ }^{1}$, Danilova E. N. ${ }^{2}$, Danilov S. V. ${ }^{2}$

1 Stavropol State Medical University, Stavropol, Russian Federation

2 Stavropol Regional Clinical Hospital, Stavropol, Russian Federation

\section{ПРОФИААКТИКА ФИБРИААЯЦИИ ПРЕАСЕРАИЙ ПОСАЕ ПРЯМОЙ РЕВАСКУАЯРИЗАЦИИ МИОКАРАА: РАНАОМИЗИРОВАННОЕ СРАВНИТЕАЬНОЕ ИССАЕАОВАНИЕ}

\author{
В. Н. Колесников ${ }^{2}$, О. И. Боева' ${ }^{1}$ А. В. ЯгоАа ${ }^{1}$, А. С. Иваненко ', Е. Н. Аанилова ${ }^{2}$, С. В. Аанилов ${ }^{2}$ \\ 1 Ставропольский госуаарственный меАицинский университет, Ставрополь, \\ Российская ФеАерация \\ 2 Краевая кАиническая больница, Ставрополь, Российская ФеАерация
}

In order to investigate the effect of Omegaven on the risk of paroxysms of atrial fibrillation lasting for more than 30 seconds, and other complications in the early postoperative period after coronary revascularization surgery, an open randomized comparative study was performed, which included 